Review

\title{
Functionalized Chitosan Nanomaterials: A Jammer for Quorum Sensing
}

\author{
Moupriya Nag ${ }^{1,+}{ }^{+}$Dibyajit Lahiri ${ }^{1,+}{ }^{+}$, Dipro Mukherjee ${ }^{1}$, Ritwik Banerjee ${ }^{1}$, Sayantani Garai ${ }^{1}$,

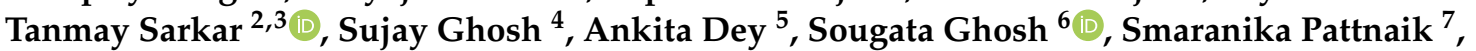 \\ Hisham Atan Edinur ${ }^{8, * \mathbb{D}}$, Zulhisyam Abdul Kari ${ }^{9, *} \mathbb{D}$, Siddhartha Pati ${ }^{10,11, * \mathbb{D}}$ and Rina Rani Ray ${ }^{5, *}$
}

check for

updates

Citation: Nag, M.; Lahiri, D.;

Mukherjee, D.; Banerjee, R.; Garai, S.;

Sarkar, T.; Ghosh, S.; Dey, A.; Ghosh,

S.; Pattnaik, S.; et al. Functionalized

Chitosan Nanomaterials: A Jammer

for Quorum Sensing. Polymers 2021,

13, 2533. https://doi.org/10.3390/

polym 13152533

Academic Editor: Marzia Marciello

Received: 9 July 2021

Accepted: 25 July 2021

Published: 30 July 2021

Publisher's Note: MDPI stays neutral with regard to jurisdictional claims in published maps and institutional affiliations.

Copyright: (C) 2021 by the authors. Licensee MDPI, Basel, Switzerland This article is an open access article distributed under the terms and conditions of the Creative Commons Attribution (CC BY) license (https:// creativecommons.org/licenses/by/ $4.0 /)$.
1 Department of Biotechnology, University of Engineering \& Management, Kolkata 700160, India; moupriya.nag@uem.edu.in (M.N.); dibyajit.lahiri@uem.edu.in (D.L.); dipmukherjee23@gmail.com (D.M.); ritwik2809@gmail.com (R.B.); sayantani0717@gmail.com (S.G.)

2 Department of Food Technology and Bio-Chemical Engineering, Jadavpur University, Kolkata 700032, India tanmay@wbscte.ac.in

3 Malda Polytechnic, West Bengal State Council of Technical Education, Government of West Bengal, Malda 732102, India

4 AMH Energy Pvt. Ltd., Kolkata 700039, India; sujayxghosh@gmail.com

5 Department of Biotechnology, Maulana Abul Kalam Azad University of Technology, Haringhata 741249, India; ankita.dey16061996@gmail.com

6 Department of Microbiology, School of Science, RK. University, Rajkot 360020, India; ghoshsibb@gmail.com

7 Department of Biotechnology and Bioinformatics, Sambalpur University, Odishsa 768001, India; smaranika2010@gmail.com

8 School of Health Sciences, Universiti Sains Malaysia, Health Campus, Kubang Kerian, Kelantan 16150, Malaysia

9 Faculty of Agro Based Industry, Universiti Malaysia Kelantan, Kota Bharu 17600, Malaysia

10 Centre of Excellence, Khallikote University, Berhampur 761008, India

11 SIAN Institute, Association for Biodiversity Conservation and Research (ABC), Odisha 756001, India

* Correspondence: edinur@usm.my (H.A.E.); zulhisyam.a@umk.edu.my (Z.A.K.); patisiddhartha@gmail.com (S.P.); raypumicro@gmail.com (R.R.R.)

+ Marked authors contributed equally.

Abstract: The biggest challenge in the present-day healthcare scenario is the rapid emergence and spread of antimicrobial resistance due to the rampant use of antibiotics in daily therapeutics. Such drug resistance is associated with the enhancement of microbial virulence and the acquisition of the ability to evade the host's immune response under the shelter of a biofilm. Quorum sensing (QS) is the mechanism by which the microbial colonies in a biofilm modulate and intercept communication without direct interaction. Hence, the eradication of biofilms through hindering this communication will lead to the successful management of drug resistance and may be a novel target for antimicrobial chemotherapy. Chitosan shows microbicidal activities by acting electrostatically with its positively charged amino groups, which interact with anionic moieties on microbial species, causing enhanced membrane permeability and eventual cell death. Therefore, nanoparticles (NPs) prepared with chitosan possess a positive surface charge and mucoadhesive properties that can adhere to microbial mucus membranes and release their drug load in a constant release manner. As the success in therapeutics depends on the targeted delivery of drugs, chitosan nanomaterial, which displays low toxicity, can be safely used for eradicating a biofilm through attenuating the quorum sensing (QS). Since the anti-biofilm potential of chitosan and its nano-derivatives are reported for various microorganisms, these can be used as attractive tools for combating chronic infections and for the preparation of functionalized nanomaterials for different medical devices, such as orthodontic appliances. This mini-review focuses on the mechanism of the downregulation of quorum sensing using functionalized chitosan nanomaterials and the future prospects of its applications.

Keywords: antibiofilm; chitosan; nanomaterial; quorum quenching; quorum sensing 


\section{Introduction}

The last decade has seen a marked increase in the development of multi-drug-resistant pathogenic organisms that have brought about significant threats for the health sector. Numerous alternative approaches are being taken to check the pathogenesis of these antibioticresistant microbes and strategies are being adopted to minimize their virulence [1,2]. The chronic-infection-causing recalcitrant microbes usually reside in the protective shield of their biofilm, which is actually a syntrophic association of microbes. Hence, exploration of the natural ways for biofilm eradication and innovations for biotechnological approaches to enhance their antibiofilm activity becomes a new and booming stream of research.

Both microbes alone and the biofilm formed by them attach themselves to specific surfaces. The biofilm-associated cells are especially capable of forming an extracellular polymeric substance matrix (EPS), which can maintain decreased growth rates and allow for up- and down regulation of some specific genes [3,4]. The EPS matrix possesses a definite construction pattern and creates an optimal condition that allows the microbes to exchange genetic contents between the cells [5]. Moreover, the biofilm-forming cells undergo cell-to-cell communication via the process of quorum sensing (QS), by which they control the expression of genetic components in response to continuous changes in the density of the cell population [6]. QS is accomplished by various types of extracellular communication materials called autoinducers (AIs) [7], which are the chemical signaling molecules that are synthesized and released by these cells [8].

Since QS plays a key role in bacterial infection and bacterial survival, eradication of the biofilm through the denaturation of the AI molecules will ensure the prevention of biofilmassociated infection. Several novel antibiofilm agents were developed for interfering with the QS cascade and thereby inhibiting the formation of biofilms $[9,10]$.

However, such interruption in cellular communication can be done via the mechanism of quorum quenching (QQ), which involves the process of disrupting the QS cascade [7]. The molecular mechanism of QQ includes the cleavage of QS signals, competitive inhibition, and acting against the major targets of QS, thereby bringing about hindrance in the maturation of biofilm.

Present-day nanomaterials are largely used as alternate therapeutics due to their large surface-area-to-volume ratio and extensive reactivity, resulting in the development of the new field of "nanomedicines" [11-13]. The enhancement in the development of antimicrobial resistance has resulted in researchers thinking about ways to provide alternate therapeutics [14]. A fascinating thing about nanomaterials is that their efficacies are largely dependent on the shape and size of the nanostructural contents of the nanomaterials and these properties can usually be distinguished well from the bulk traditional material, which possesses the appearance of a continuous material [15]. This is why these nanomaterials create huge interest regarding their applications in different types of research and development fields related to biotechnology, biology, chemistry, biophysics, and many others [16].

In order to surpass the existing drawbacks of nanomaterials, there has recently been development of innovative functionalized nanomaterials with potential applications in various healthcare domains. For covering the nanoparticle core surface with a capping agent [17], the surface of nanomaterials can be functionalized using either a covalent modification strategy via a standard organic synthesis procedure or using a noncovalent modification complexation, adsorption process, or grafting strategy [18].

Several researchers are trying to use functionalized nanoparticles to resist biofilm formation, where gold particles (GNPs) functionalized with enzyme proteinase K were found to be effective against Pseudomonas fluorescens biofilms [19]; silica nanoparticles functionalized with either peppermint oil (P-Cap) alone or in combination with cinnamaldehyde (CP-Cap) were found to halt the complex biofilm formation of Pseudomonas aeruginosa, E. coli DH5, S. aureus, and Enterobacter cloacae [20]; and amine-, carboxylate-, and isocyanate-functionalized superparamagnetic-iron oxide nanoparticles (IONs) against $S$. aureus biofilms are noteworthy [21]. Gold-nanoparticle-functionalized liposomes containing 
tobramycin could decrease biofilm biomass by approximately 1.5 times as compared to untreated liposomes containing tobramycin only [22]. A catheter surface that was functionalized with $\mathrm{MgF}(2)$ nanoparticles (NPs) effectively removed the biofilm from it [23]. Gold nanoparticles (GNPs) and gold nanocomposites functionalized with antimicrobial peptide Pediocin AcH and Listeria adhesion protein (LAP) (GNP-Pediocin-LAP) were successfully used to remove biofilms of Listeria sp. [24].

Metals and metal oxide nanoparticles (NPs) were associated with inorganic and organic supports to improve their antibacterial activity and stability. These nanomaterials can be triggered by various mechanisms (such as changes in $\mathrm{pH}$, light, magnetic fields, and the presence of bacterial enzymes); additionally, they can improve antibacterial efficacy and reduce side effects and microbial resistance [25].

Apart from functionalized metal nanoparticles, functionalized chitosan nanoparticles were also found to enhance photodynamic therapy and thereby have a $100 \%$ bactericidal activity against Enterococcus faecalis [26]. Actually, chitosan is often preferred for use as the component of nanomaterials due to its biocompatibility, verified low toxicity verified, bioand muco-adhesivity, biodegradability, etc. [27-30].

This review discusses the functionalization of chitosan nanoparticle and elucidation of its efficacy in interrupting/blocking the quorum sensing (QS) signal to halt biofilm formation.

\section{Quorum Sensing in Biofilm-Associated Microbes}

QS, being the key event behind biofilm formation, is the main target for blocking to achieve an antibiofilm effect. Apart from biofilm formation, QS regulates multiple processes that involve sporulation, bioluminescence, the production of various types of virulence factors, antibiotic biosynthesis, and the formation of biofilms [31,32]. The mechanism of QS in Gram-negative bacteria (Table 1) takes place via LuxI/LuxR type systems, which play an important role in the production of AIs, the signalling molecules [33].

Table 1. Quorum-sensing (QS) systems of selected Gram-negative bacteria.

\begin{tabular}{|c|c|c|c|c|c|}
\hline SL No. & $\begin{array}{c}\text { Bacterial } \\
\text { Organism Name }\end{array}$ & Quorum-Sensing Molecules & Genes & Receptors & References \\
\hline \multirow{3}{*}{1.} & \multirow{3}{*}{$\begin{array}{c}\text { Chromobacterium } \\
\text { violaceum }\end{array}$} & C12-HSL & N.A. & N.A. & [34] \\
\hline & & N.A. & N.A. & SdiA & [35] \\
\hline & & $\mathrm{AI}-2$ & LuxS & LsrB & {$[16,36]$} \\
\hline \multirow{4}{*}{2.} & \multirow{4}{*}{$\begin{array}{l}\text { Pseudomonas } \\
\text { aeruginosa }\end{array}$} & C4-HSL & RhlI & RhlR & [37] \\
\hline & & 3-oxo-C12-HSL & LasI & LasR & {$[38,39]$} \\
\hline & & 3-oxo-C12-HSL & $N A$ & QscR & {$[3,40]$} \\
\hline & & PQS, HHQ & $\begin{array}{c}\text { PqsABCD, } \\
P q s H\end{array}$ & PqsR & [41] \\
\hline \multirow{3}{*}{3.} & \multirow{3}{*}{$\begin{array}{l}\text { Staphylococcus } \\
\text { aureus }\end{array}$} & 3-hydroxy-C4-HSL & LuxM & LuxN & {$[3,40]$} \\
\hline & & AI-2 & LuxS & LuxP & {$[42]$} \\
\hline & & CAI-1 & CqsA & CqsS & [43] \\
\hline 4. & $\begin{array}{l}\text { Acinetobacter } \\
\text { baumannii }\end{array}$ & 3-hydroxy-C12-HSL & $A b a I$ & AbaR & [44] \\
\hline \multirow{3}{*}{5.} & \multirow{3}{*}{ Escherichia coli } & 3-oxo-C8-HSL & N.A. & SdiA & {$[27,35]$} \\
\hline & & $\mathrm{AI}-2$ & LuxS & LsrB & {$[37,45,46]$} \\
\hline & & AI-3/Epinephrine/Norepinephrine & N.A. & QseC & {$[47]$} \\
\hline \multirow{3}{*}{6.} & \multirow{3}{*}{$\begin{array}{c}\text { Klebsiella } \\
\text { pneumoniae }\end{array}$} & C8-HSL & N.A. & N.A. & {$[15,36]$} \\
\hline & & C12-HSL & N.A. & N.A. & [27] \\
\hline & & AI-2 & LuxS & LsrB & {$[48,49]$} \\
\hline
\end{tabular}




\section{Chitosan Nanoparticles}

A biofilm matrix acting as a scaffold provides a protective covering for sessile bacteria, making them drug resistant [50]. Hence, a more effective drug delivery system needs to be applied that can target both the biofilm matrix and the embedded sessile bacterial cells. Chitosan and its derivatives, with their acclaimed biofilm inhibiting property, may be used but in a more precise manner to halt the quorum sensing.

Nanoparticles, with atomic dimensions of $10 \AA$ to $100 \AA$ [51] were shown to be quite effective for drug delivery. Despite a few drawbacks, including poor absorption and dissolution rate with reduced bioavailability, using nanoparticles is a much safer method, as these microscopic particles act as nanocarriers, encasing high drug payloads and provide more targeted action with a controlled release.

Chitin, a natural polymer of $\beta$-(1,4)-N-acetyl-D-glucosamine, turns into chitosan, a polysaccharide composed of $\mathrm{N}$-acetylglucosamine and D-glucosamine units [52], upon deacetylation in the presence of an alkali. Due to its cationic nature, biodegradability, compatibility, and nontoxicity, chitosan is used extensively by nano-biomedical researchers [53-55] for the delivery and controlled release of biomolecules, such as proteins, peptides, enzymes, genes, vaccines, and small drug molecules [56] via various delivery routes, including oral, buccal, vaginal, and pulmonary. Chitosan NPs are also used as vaccine adjuvants due to the mucoadhesive properties of chit, which can stimulate the cells of the immune system [57]. Some of the important properties of chitosan that have led to its wide range of applications in various fields (such as NPs) include mucoadhesion (as shown by trimethyl chitosan and carboxymethyl chitosan) [58]; controlled drug release, which enhances its effectiveness for drug delivery [59]; permeation enhancement, as shown by trimethyl chitosan [60]; antibacterial activity; no cytotoxicity; biocompatibility; and biodegradability. These properties are incredibly advantageous for the advancement of biocompatible and biodegradable medication conveyance frameworks [61,62].

Since its first emergence in the mid-1990s, the chitosan nanoparticle (ChNP) has been used for drug delivery [63]. The property that is responsible for the success of ChNPs in drug delivery is its ability to bind with negatively charged anions to form beads. However, beads larger than approximately $2 \mathrm{~mm}$ generally hinder this process [64]. The discovery of the ChNPs involves various 'bottom-up' or 'top-down' approaches, or a synergistic combination of both techniques. However, among the regular 'bottom-up' methods, the most popular ones are ionotropic gelation and the polyelectrolyte complex method [65] due to their straightforwardness and non-requirement of high shear power and natural solvents [66], unlike the 'top-down' methods of milling, ultrasonication, and high-pressure homogenization [62,67].Irrespective of the methodology adopted for their preparation, the ChNPs are regularly used for drug delivery to combat several diseases with appreciable efficacy (Table 2). Although the precise mode of antimicrobial action is not determined completely, it was proposed that the molecular structure of chitosan is imperative for its antimicrobial activities. The antibacterial potential of chitosan is strongly influenced by several factors, such as its type, degree of polymerization, and physicochemical properties.

\subsection{Preparation of Chitosan Nanoparticles (ChNPs)}

ChNPs were first prepared in the mid-1990s by scientist Ohya and his colleagues, who used the method of emulsifying and cross-linkage for the site-specific intravenous delivery of the anti-cancer drug (5-fluorouracil) [63]. The property that is responsible for the success of ChNPs in drug delivery is its ability to bind with negatively charged anions to form beads. However, beads larger than approximately $2 \mathrm{~mm}$ generally hinder this process [64] The discovery of the ChNPs involves various 'bottom-up' or 'top-down' approaches, or a synergistic combination of both techniques. Currently, five methods are widely used for the synthesis of ChNPs. The 'bottom-up' methods include ionotropic gelation, microemulsion method, emulsification solvent diffusion/evaporation method, reverse micellar method and polyelectrolyte complex method [65]. Among these aforesaid methods, the most popular ones are ionotropic gelation and polyelectrolyte complex method. These techniques 
are straightforward and do not require high shear power or utilize natural solvents [66]. On the other hand, the 'top-down' methods are milling, ultrasonication, and high-pressure homogenization $[62,67]$. Figure 1 is a schematic representation of the various methods that are employed for the synthesis of ChNPs.

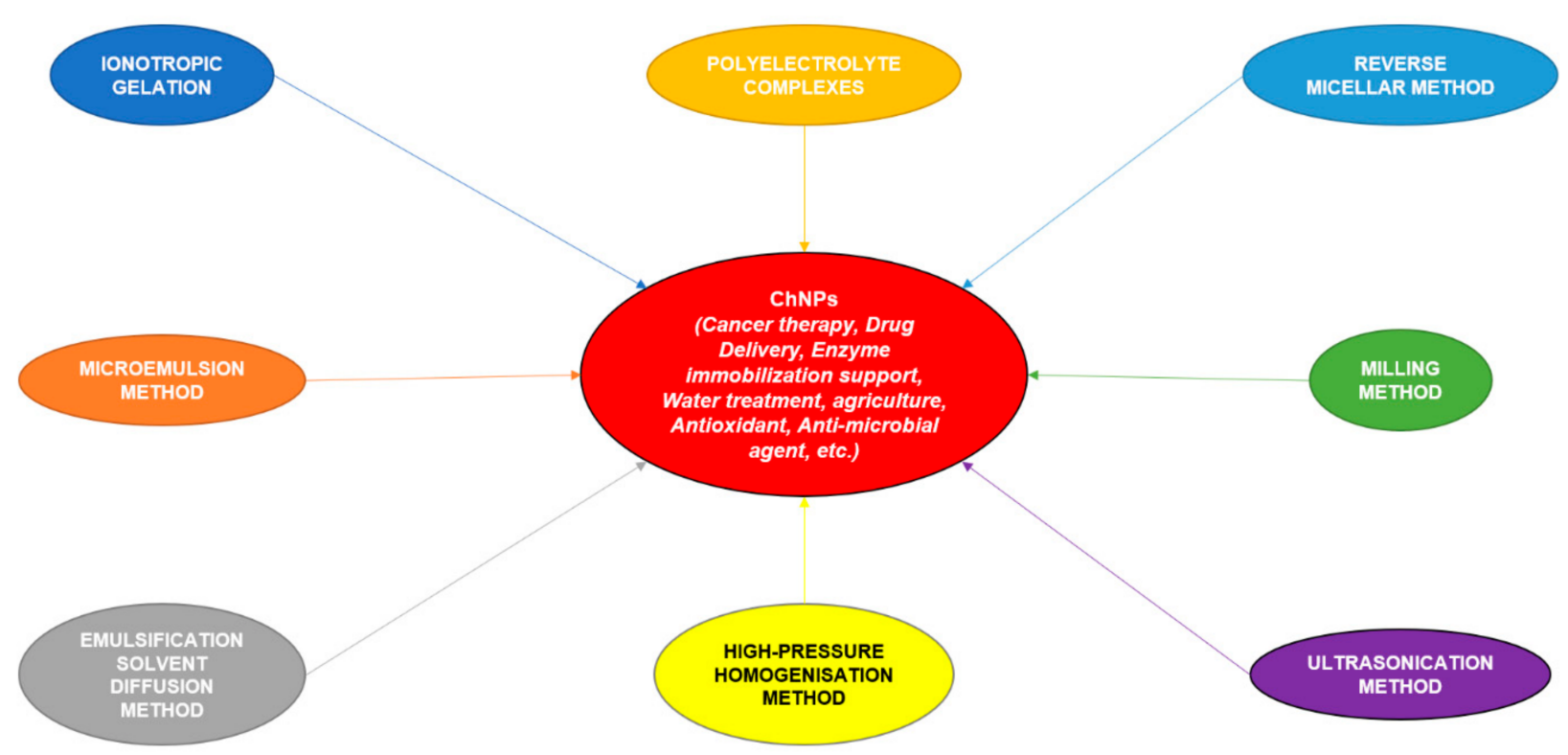

Figure 1. Schematic representation of the various methods employed for ChNP synthesis.

\subsubsection{Ionotropic Gelation}

This method makes use of the crosslinking of the electrostatic bond between the amine groups of the chitosan to a polyanionic crosslinker, such as tripolyphosphate (TPP). The ionotropic gelation method for chitosan nanoparticle synthesis was first investigated by Calvo et al. in 1997 [68]. Ch can be dissolved in the presence or absence of a stabilizing agent (such as poloxamer) in acetic acid. This aqueous acidic solution of chitosan is then added dropwise to a TPP solution, with continuous and steady mechanical stirring at room temperature. Given that TPP is anionic, it will spontaneously crosslink with chitosan, forming chitosan-TPP NPs. This resulting product can successfully trap drug molecules and is able to carry them to a target. Hence, these nanocarriers were later developed into suitable drug delivery mechanisms. The dimensions and the charge on the surface can be changed by altering the chitosan-stabilizer ratio [69]. Alterations in the chitosan concentration and the polymer-to-polyanion ratio and an increase in the particle condensation and dimensions are also observed [70]. It was also reported that stability was increased when the NPs were added to a saline solution. This is because when monovalent sodium chloride salt is added to the solvent, there is an electrostatic repulsion between it and the amino group (positively charged) on the chitosanic backbone. This process decreases the particle size of the nanoparticles in the solution and increases the flexibility of the polymer chains, which helps to increase their stability [71].

In 2018, Furtado et al. reported the synthesis of chitosan and sodium fluoride (Ch-NaF) nanoparticles using this method [72]. This method is generally considered safe since it removes the dangers and toxicity that are associated with the use of organic solvents; it is also considered simple and easy with the use of an aqueous medium [62]. However, the nanoparticles synthesized using this method of ionotropic gelation generally have low mechanical strength [73]. 


\subsubsection{Microemulsion Method}

This method was first reported by De et al. in 1999 [74] and involves the use of four components: polymer, surfactant, and a crosslinker. According to this method, a surfactant was dissolved in an organic solvent (n-hexane and toluene) and chitosan in an acetic acid solution. Glutaraldehyde (commonly used crosslinker for this method) was added to the surfactant/hexane and toluene mixture at room temperature, with continuous and steady mechanical stirring applied overnight, which completes the crosslinking process between the amino group of chitosan and glutaraldehyde, which acts as a crosslinker [75]. Subsequently, nanoparticles are formed. The main mechanism behind this crosslinking process is the Schiff reaction and comprises the mixture of the two solutions in the solvents, followed by the removal of excess surfactant as a precipitate with calcium chloride $\left(\mathrm{CaCl}_{2}\right)$; then, the precipitate was removed using centrifugation to yield the desired polymer crosslinker nanoparticles [76].

However, the major drawback of this method lies in the use of the antigenic crosslinker agent glutaraldehyde [69]. Additionally, the integration of the peptide molecules to the synthesized nanoparticles may be hindered by the crosslinking and, thus, is not possible [68].

\subsubsection{Emulsification Solvent Diffusion Method}

This improved method employed PGLA was first reported in 2002 [77] and is based on a method developed by Niwa et al. in 1993 [78]. A biological phase is injected into a chitosan solution with a poloxamer to enhance the stability of the solution; then mechanical stirring is applied, followed by a high-pressure homogenization technique to yield an emulsified mixture, which is diluted with water in the subsequent steps. The water used for dilution diffuses into the organic layer, which helps in the formation of the nanoparticles. The use of high shear forces during the synthesis of the nanoparticles and the involvement of organic solvents are the major limitations of this method [69].

\subsubsection{Polyelectrolyte Complexation (PEC) Method}

Unlike any other method listed above, this method of chitosan nanoparticle synthesis involves the bond between the positively charged amino groups of chitosan and the anionic carboxylic group of dextran or alginate groups of dextran sulfate, which finally results in the neutralization of the charges. The self-assembly of the polyelectrolyte complexes occurs due to the charge neutralization via the addition of acidic chitosan solution into the anionic dextran solution with continuous mechanical stirring at room temperature $[79,80]$. Nanoparticles that carry insulin molecules to their target site were reported by the scientists to be manufactured by the process of alginate ionotropic pre-gelation and then subsequently by polyelectrolytic complexation with chitosan for diabetic patients [81]. Chitosan nanoparticles incorporated with gum are manufactured using the PEC method for bone regeneration therapy [82].

\subsubsection{Reverse Micellar Method}

The most significant feature of this process is, unlike the other methods, the absence of both a crosslinker and poisonous natural solvents. Furthermore, ultrafine nanoparticles inside a restricted size reach can be acquired with this technique. This process can be described as the application of chitosan into the natural solvent containing the surfactant while the mixture is continuously agitated via mechanical stirring overnight to form the reverse micelles [83]. This method for the synthesis of ChNPs was first reported by a group of scientists in 2008 [84].

According to the recent trends and literature, among all the methods employed for the production of nanoparticles using chitosan, the most preferred and popular method is ionotropic gelation, which involves the ionic interaction between the cationic chitosan amine group and the anionic polymeric materials. This charge-based association of adversely charged drug payloads isa more manageable ionic gelation technique, bringing about a high drug encapsulation efficiency and optimal drug release such that the en- 
trapment efficiency fluctuates between 0.3 to 0.98 and that of the drug release fluctuates between 0.4 and 0.8 [85]. The second-most common technique is polyelectrolyte complexation, which includes the crosslinking of chitosan with the molecules of the drug and results in a slowed drug discharge rate. Based on the literature evidence, the methods that are used to a lesser extent include solvent evaporation, coprecipitation, and emulsion droplet methods due to their poor entrapment efficiency and poor cargo release profile [62].

Table 2. ChNPs: preparation methods for various diseases, drugs, efficiencies, and advantages.

\begin{tabular}{|c|c|c|c|c|c|}
\hline $\begin{array}{l}\text { Method of } \\
\text { Preparation }\end{array}$ & Diseases & Drug in ChNPs & Efficiency & Advantages & Reference \\
\hline \multirow{10}{*}{$\begin{array}{l}\text { Ionotropic } \\
\text { gelation }\end{array}$} & Bladder cancer & $\begin{array}{c}\text { Chitosan-hyaluronic acid } \\
\text { dialdehyde NPs (for } \\
\text { CD44-targeted siRNA } \\
\text { delivery) }\end{array}$ & $\mathrm{LE} \geq 0.95$ & Cytotoxicity is reduced & [86] \\
\hline & Migraine & Sumatriptan succinate & $\mathrm{EE}=0.60$ & $\begin{array}{l}\text { Targeted specific drug } \\
\text { delivery }\end{array}$ & [87] \\
\hline & $\begin{array}{l}\text { S. pneumoniae } \\
\text { infections }\end{array}$ & Cpl-1-loaded ChNPs & $\mathrm{EE}=0.60$ & $\begin{array}{l}\text { Enhanced bioavailability of } \\
\text { the drug and in vivo half-life; } \\
\text { chitosan biocompatibility for } \\
\text { drug delivery }\end{array}$ & {$[65]$} \\
\hline & Immuno-therapy & $\begin{array}{c}\mathrm{CpG} \\
\text { oligodeoxynucleotide }\end{array}$ & $\begin{array}{c}\mathrm{EE}= \\
0.90-0.97\end{array}$ & $\begin{array}{c}\text { Better immune-stimulation, } \\
\text { cell uptake, and binding } \\
\text { abilities }\end{array}$ & [88] \\
\hline & $\begin{array}{l}\text { Antimicrobial } \\
\text { activity against } \\
\text { MRSA }\end{array}$ & $\begin{array}{c}\mathrm{N}^{\prime}-((5-\text { nitrofuran-2-yl }) \\
\text { methylene })-2- \\
\text { benzohydrazide } \\
{[(\mathrm{CH}-5-\mathrm{NFB}-\mathrm{NP})]}\end{array}$ & $\mathrm{EE}=0.45$ & $\begin{array}{c}\text { Antibacterial property } \\
\text { increased; effective against } \\
\text { multi-drug-resistant strains; } \\
\text { easy production method }\end{array}$ & [89] \\
\hline & Acne & Clindamycin & $\mathrm{EE}=0.42$ & $\begin{array}{l}\text { Better drug distribution; } \\
\text { specific target delivery }\end{array}$ & [90] \\
\hline & $\begin{array}{l}\text { Administration of } \\
\text { antioxidant } \\
\text { peptides }\end{array}$ & $\begin{array}{l}\text { Goby fish protein } \\
\text { hydrolysate }\end{array}$ & $\mathrm{EE}=0.61$ & $\begin{array}{l}\text { Better thermal stability and } \\
\text { antioxidant properties; } \\
\text { controlled diffusion } \\
\text { mechanism }\end{array}$ & [91] \\
\hline & Hyperlipidemia & $\begin{array}{c}\text { Sodium alginate } \\
\text { entrapping rosuvastatin }\end{array}$ & - & Controlled drug release & [92] \\
\hline & $\begin{array}{l}\text { Phylloquinone } \\
\text { induced prolonged } \\
\text { blood circulation } \\
\text { time }\end{array}$ & VK1 & $\mathrm{EE}=0.79$ & $\begin{array}{l}\text { Constant release of vitamin } \\
\text { K1; circulation time of } \\
\text { RBC-hitchhiking chitosan NPs } \\
\text { greater than regular NPs }\end{array}$ & [93] \\
\hline & Polycystic kidney & Metformin & $\mathrm{LE}=0.33$ & $\begin{array}{l}\text { Enhanced bioavailability; } \\
\text { lesser side effects in other } \\
\text { parts of the body; better } \\
\text { pharmaceutical efficacy }\end{array}$ & [94] \\
\hline \multirow{2}{*}{$\begin{array}{l}\text { Polyelectrolyte } \\
\text { complexation } \\
\text { (PEC) }\end{array}$} & Cancer & $\begin{array}{l}\text { Amygdalin entrapped by } \\
\text { alginate }\end{array}$ & $\mathrm{EE}=0.90$ & $\begin{array}{l}\text { Stable release of the drug; low } \\
\text { toxicity to cells }\end{array}$ & [95] \\
\hline & Gene therapy & siRNA & - & $\begin{array}{l}\text { Safer technique with } \\
\text { increased stability }\end{array}$ & [96] \\
\hline \multirow{2}{*}{$\begin{array}{l}\text { Double } \\
\text { emulsion } \\
\text { crosslinking } \\
\text { method }\end{array}$} & Cancer treatment & 5-Fluorouracil & $\mathrm{EE} \approx 0.60$ & $\begin{array}{c}\text { Increased inhibition of cancer; } \\
\text { controlled drug release; } \\
\text { increased efficiency of } \\
\text { entrapment }\end{array}$ & [97] \\
\hline & $\begin{array}{c}\text { Capillary } \\
\text { hemangioma }\end{array}$ & Propranolol hydrochloride & $\mathrm{EE} \geq 0.50$ & $\begin{array}{l}\text { Minimal side effects; } \\
\text { sustained drug release }\end{array}$ & [98] \\
\hline
\end{tabular}


Table 2. Cont.

\begin{tabular}{|c|c|c|c|c|c|}
\hline $\begin{array}{l}\text { Method of } \\
\text { Preparation }\end{array}$ & Diseases & Drug in ChNPs & Efficiency & Advantages & Reference \\
\hline $\begin{array}{l}\text { Microemulsion } \\
\text { method }\end{array}$ & Diabetes & Insulin & $\mathrm{EE}=0.80 \%$ & $\begin{array}{l}\text { Enhanced availability of the } \\
\text { drug at the site (due to its } \\
\text { interaction with the mucosal } \\
\text { membrane of the intestine) } \\
\text { and prolonged release of the } \\
\text { drug; better compliance of } \\
\text { oral delivery in patients }\end{array}$ & [99] \\
\hline \multirow[t]{2}{*}{ Crosslinking } & $\begin{array}{l}\text { Antimicrobial } \\
\text { effects }\end{array}$ & $\begin{array}{l}\text { Naringenin (NRG), } \\
\text { quercetin (QE), and } \\
\text { curcumin (CUR) } \\
\text { conjugated with } \\
\text { L-histidine and } \mathrm{ZnO}\end{array}$ & $\begin{array}{l}\text { LE varies } \\
\text { from } 0.89 \text { to } \\
0.92\end{array}$ & $\begin{array}{l}\text { Noticeable antimicrobial } \\
\text { action against Trichophyton } \\
\text { rubrum and Staphylococcus } \\
\text { aureus strains because of the } \\
\text { cumulative impact }\end{array}$ & [100] \\
\hline & Breast cancer & Methotrexate & $\mathrm{LE}=0.13$ & $\begin{array}{l}\text { Sustainable drug release; } \\
\text { improved drug loading } \\
\text { efficacy }\end{array}$ & [101] \\
\hline $\begin{array}{l}\text { Droplet } \\
\text { emulsion } \\
\text { method }\end{array}$ & Glaucoma & $\begin{array}{l}\text { Trimethylchitosan (TMC) } \\
\text { and tetrandrine lipid NPs } \\
\text { (TET-LNPs)-loaded } \\
\text { carboxy-methylchitosan } \\
\text { (CMC) or } \\
\text { hydroxypropylchitosan } \\
\text { (HPC) }\end{array}$ & $\mathrm{LE} \geq 0.9$ & $\begin{array}{l}\text { Increased bioavailability and } \\
\text { retention time }\end{array}$ & [102] \\
\hline $\begin{array}{l}\text { Co- } \\
\text { precipitation }\end{array}$ & $\begin{array}{l}\text { Arthritis } \\
\text { (rheumatoid) }\end{array}$ & Meloxicam & $\mathrm{EE}=0.82$ & $\begin{array}{l}\text { Lesser dosage frequency and } \\
\text { toxicity }\end{array}$ & [103] \\
\hline- & Antioxidant & Resveratrol & $\mathrm{EE} \geq 0.90$ & $\begin{array}{l}\text { Continuous release of the } \\
\text { drug and enhanced storage } \\
\text { and stability of the drug }\end{array}$ & [48] \\
\hline $\begin{array}{l}\text { Nano- } \\
\text { precipitation }\end{array}$ & $\begin{array}{l}\text { Parkinson's } \\
\text { Disease }\end{array}$ & $\begin{array}{l}\text { Ropinirole hydrochloride } \\
\text { coated with PGLA }\end{array}$ & $\mathrm{LE}=0.05$ & $\begin{array}{l}\text { Can cross the blood-brain } \\
\text { barrier; hepatic metabolism; } \\
\text { delivers the drug to the } \\
\text { specific site of action }\end{array}$ & [49] \\
\hline
\end{tabular}

\subsection{Development of Functionalized ChNPs}

Chitosan possesses suitable functional groups that help with providing some specific properties to the polysaccharides. The structural and functional properties of chitosan become enhanced due to the presence of an amino group being present at the $\mathrm{C}-2$ position. This group helps with providing the cationic nature, thus providing chitosan with various properties that include antimicrobial, wound healing, and mucoadhesive properties. The pKa value makes chitosan insoluble in water but soluble in various types of acidic solutions [104,105]. The mechanism of functionalization results in the development of $\mathrm{N}$-modified, O-modified, and N,O-modified chitosan, thereby providing chitosan with a wide range of biological activities. The functionalization of chitosan via the use of quarternized N-alkyl or N-benzylchitosan or phosphorylation of the chitosan helps with the enhancement of the antimicrobial activity. O-modified chitosan is free to undergo the mechanism of $\mathrm{N}$-modified derivatives when using $\mathrm{H}_{2} \mathrm{SO}_{4}$ or $\mathrm{MeSO}_{3} \mathrm{H}$ via the process of protonation of the amine group through the removal of hydroxyl group; this process is used for the purpose of protecting various types of hydroxyl groups [106]. Studies showed that cinnamaldehyde crosslinks with chitosan not only enhances its stability but also increases the antimicrobial efficacy of ChNPs $[107,108]$. It was also observed that ChNPs synthesized using the leaf extract of Caltharanthus roseus showed a size-dependent drug entrapment efficiency [109]. 


\section{Inhibition of Biofilm Formation Using Functionalized Chitosan Nanoparticles}

However, in order to target biofilm-associated chronic infections, medical devices, and food industries [110], the ChNPs must have the ability to block quorum sensing. It was revealed from various experimental observations that the positively charged ChNPs are usually loaded in Oxa or oxacillin and ChNP-DNase-Oxa or Deoxyribonuclease I [111]. The anti-biofilm activity is generally studied against the biofilm network formed by nosocomial bacterial species, such as Staphylococcus aureus and Pseudomonas aeruginosa. Biofilm structuring on silicone surfaces was checked and researched with the help of SEM or scanning electron microscopy [112]. Confocal laser scanning microscopy (CLSM) was used for looking upon alive or dead microorganisms inside the biofilm matrix, which revealed that ChNP-DNase-Oxa had a higher level of anti-biofilm activity than the Oxa-mixed nanoparticles, which is present without the ChNP-Oxa or the DNase and the summation of Oxa and DNase, which involves free Oxa $[41,113]$. Both the formation of new biofilms and the eradication of mature biofilms in vitro could be achieved with the help of the ChNP-DNase-Oxa. Actually, through the denaturation of eDNA, ChNP-DNase-Oxa can damage the biofilm matrix, decrease the width of the biofilm, and the number of viable cells on silicone. Back-to-back treating with the help of ChNP-DNase-Oxa over two days was seen to give a shocking and successful result of almost a 99\% decrease in the biofilm [114]. Moreover, ChNP-DNase-Oxa was found to be effective against the biofilm of any type of normal and clinical strains of Staphylococcus aureus [113].

This shows the high potential and effectivity of nanoparticles for treating the infections associated with biofilms [115]. Attenuation of the signals of bacterial quorum sensing can inhibit infection and can also stop the generation of bacterial virulence. Many research works have been conducted and almost all of them showed that the natural compounds possess more effectiveness over artificially synthesized chemicals regarding their treatment of biofilms and establishing them as anti-quorum-sensing agents.

Especially, flavonoid compounds are highly efficient anti-microbial and antibiofilm compounds. However, due to the very low or no dissolution of the flavonoid molecules and the rare bioavailability, minimal application of flavonoids is found [116]. Experimental observations revealed that phytochemicals, when mixed with chitosan nanoparticles, significantly decreased the QS activity through the inactivation of AI molecules [117]. Kaempferol, a flavonoid, is known to possess high-anti-quorum-sensing activity [118]. The application of the kaempferol and chitosan nanoparticles was analyzed on the basis of their properties of hydrogen bonding, hydrodynamic diameter, antioxidant activity, and amorphous transformation. After this, the inhibition of the quorum-sensing molecules by the nanoparticles in a time-dependent pattern is usually studied [119]. This measurement is done in a violacein pigment with the help of a biosensor strain Chromobacterium violaceum CV026, which is again operated by an AI known as acylated homoserine lactone (AHL) [120]. Kaempferol-loaded sodium tripolyphosphate (TPP)on ChNPshave typical particle sizes and zeta potentials of 190 to $200 \mathrm{~nm}$ and +30 to $+35 \mathrm{mV}$, respectively, and can be stored up to 30 days and still successfully inhibit the quorum-sensing molecules, namely, the violacein pigment, in Chromobacterium violaceum CV026 [121]. After the success of this method, attempts are being made to use it as a novel antimicrobial chemotherapy. In this process, the kaempferol-encapsulated chitosan nanoparticles play the role of a stable and effective quorum-sensing-dependent antimicrobial, antibacterial, and antibiofilm agent [122].

Quercetin (QUE), another flavonoid phytocompound that is found in many commonly used medicinal plants [123] holds strong potential for establishing itself as a QS-inhibiting agent against Staphylococcus aureus, Pseudomonas aeruginosa, etc. [124]. However, the effective laboratory application of quercetin alone has stopped because of its lesser solubility in physiological fluids [125]. Therefore, many research works convey a solubility increase strategy for quercetin, which is done in the form of an amorphous and stable complex of nanoparticles of quercetin and chitosan [126]. The preparation of this complex is done using an electrostatic method and it is performed to form a complex involving ionized 
quercetin components and oppositely charged ChNPs [127]. In optimal conditions, a quercetin and chitosan nanoparticle complex with a size of roughly 150 to $170 \mathrm{~nm}$ shows a payload of about 25 to $30 \%$ having 60 to $70 \%$ efficiency with a long storage ability. Due to the absence of any adverse side effects, the complex of quercetin and ChNPs can be used for various therapeutic purposes. Such a complex is found to be more effective in the inhibition of quorum sensing than quercetin alone. Although this complex could bring about the increased suppression of quorum-sensing-regulating genes, resulting in the haltingof swimming motility and formation of Pseudomonas aeruginosa biofilms, it could not suppress the formation of its virulence factor [46]. The prior inhibition of the production of the biofilm's swimming motility using the quercetin and ChNPs complex revealed an almost five-fold increase in kinetic solubility [128].

A new type of ChNPsthat are dually crosslinked with genipin and sodium tripolyphosphate (TPP) display quorum quenching activity [129].

Trans-cinnamaldehyde (CA) is an intensively studied compound that was shown to inhibit QS activity by decreasing the DNA-binding ability of LuxR while inhibiting acyl-homoserine lactone production. In this work, chitosan-based nanocapsules laden with a high concentration of CA were applied to a transformed E. coli Top 10 strain fluorescencebased reporter [14,130].

\section{Mechanism of QS Inhibition Using Functionalized Chitosan Nanoparticles}

A nanocapsule is a shell made from a nontoxic polymer that encapsulates an inner liquid core at the nanoscale. These have many uses, including promising medical applications for drug delivery, food enhancement, nutraceuticals, and self-healing materials. The benefits of encapsulation methods are the protection of the drug and/or allied substances from the adverse environment, controlled release, and precision targeting. Hence, chitosan in the form of nanoparticles can exert its antibiofilm activity in a more targeted way. TPP-crosslinked nanoparticles (ionically crosslinked; IC-NPs) show considerable anti-quorum-sensing activity despite their inherent colloidal instability in microbiological media.

It was found that nanocapsules can interact with bacteria via electrostatic interaction, thus effectively delivering the quorum-quenching compound $\mathrm{CA}$ to the bacteria. The electrostatic adsorption of the chitosan-coated nanocapsules to the bacterial cell envelope is the mechanism that underpins the observed enhancement of the QS inhibition activity [131].

The polycationic groups in organic nanoparticles that are used for antimicrobial activity cause cell damage, perhaps via an ion exchange interaction between bacteria and charged polymer surfaces, resulting in the disruption of cellular membranes [132]. Polycationic nanoparticles can enter into cells via endocytosis, followed by the formation of nanoscale membrane holes, which leads to a final membrane translocation. [133]. The mechanism of interaction of nanoparticles on the cell surface was also reported in terms of the adsorption and penetration (or disruption) of cell membranes, triggering NP-mediated toxicity. This may include steps such as nanoparticle adhesion at the membrane/water interface, passive membrane translocation, membrane restructuring and leakage, and adhesive lipid extraction [134]. Nanoparticle translocation into a cell is observed to occur via the outer wrapping, followed by free translocation and inner attachment and embedment [135]. The adsorption of NPs leads to cell wall depolarization, inducing cellular toxicity and degradation, which allows ions to enter the cytosol. Sometimes, NPs cause irregular pits on the cell wall surface, enabling ions to enter the cell [136]. The polysaccharides of EPS interact with $\mathrm{SO}_{4}$ groups of functionalized polystyrene NPs via hydrophobic complexation, which disrupts bacterial biofilm formation [137].

Quaternary ammonium chitosan NPs can produce long cationic polymer chains that penetrate the cell membrane and can induce ion exchange, which disrupts biofilms [138].

The positive surface of QAS ciprofloxacin-loaded nanochitosan-coated Ti implants disintegrates the negatively charged bacteria, followed by the release of ciprofloxacin, which inhibits enzymes, including DNA gyrase, and topoisomerase causes bacterial disruption. 
Free radicals interact with endogenous molecular oxygen to produce ROS, superoxide hydroxyl radicals, and hydrogen peroxide, which damages the bacteria membrane integrity and causes irreparable bacteria lysis [139]. Quaternized-chitosan-loaded Ag NPs release Ag ions that disintegrate the bacteria and inhibit biofilm development [140] (Figure 2).

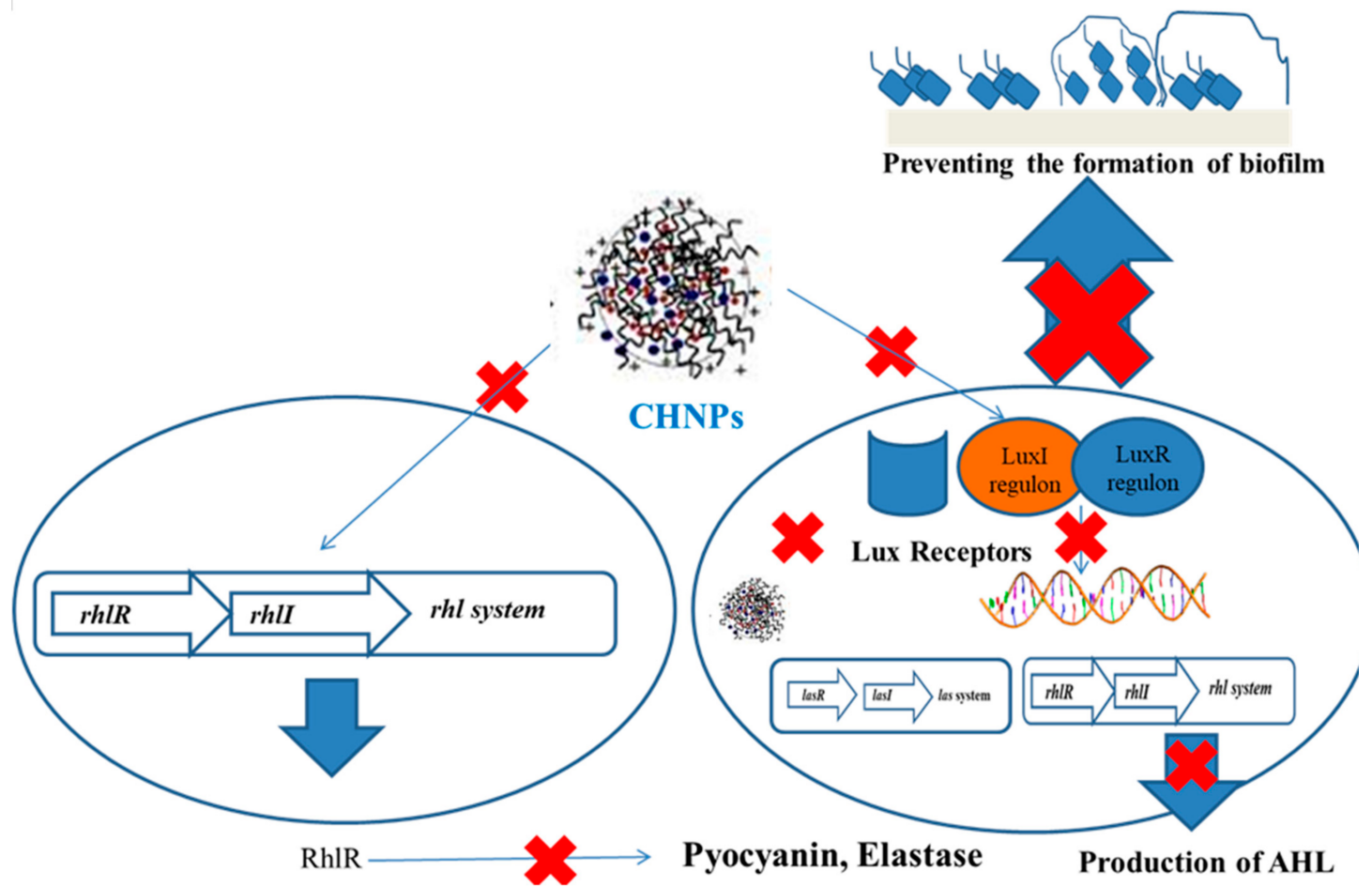

Figure 2. Mechanism of inhibition of biofilm by ChNPs.

\section{Conclusions}

After surface functionalization with various bioactive compounds, chitosan nanoparticles become well equipped for quorum quenching. The success of biofilm eradication lies with the precise obstruction of the transmission of signal molecules for cell-to-cell communication. More research is warranted to find out potent bioactive compounds that can be used for the functionalization of chitosan nanoparticles for various successful therapeutic applications.

Funding: The work was supported by Universiti Sains Malaysia and Universiti Malaysia Kelantan.

Institutional Review Board Statement: Not applicable.

Informed Consent Statement: Not applicable.

Data Availability Statement: Not applicable.

Conflicts of Interest: The authors declare no conflict of interest.

\section{References}

1. Schuster, M.; Sexton, D.J.; Diggle, S.P.; Greenberg, E.P. Acyl-homoserine lactone quorum sensing: From evolution to application. Annu. Rev. Microbiol. 2013, 67, 43-63. [CrossRef]

2. Rasko, D.A.; Sperandio, V. Anti-virulence strategies to combat bacteria-mediated disease. Nat. Rev. Drug Discov. $2010,9,117-128$. [CrossRef]

3. dos Reis Ponce, A.; Martins, M.L.; de Araujo, E.F.; Mantovani, H.C.; Vanetti, M.C.D. AiiA quorum-sensing quenching controls proteolytic activity and biofilm formation by Enterobacter cloacae. Curr. Microbiol. 2012, 65, 758-763. [CrossRef]

4. Wu, C.; Yan, Y.; Wang, Y.; Sun, P.; Qi, R. Antibacterial epoxy composites with addition of natural Artemisia annua waste. e-Polymers 2020, 20, 262-271. [CrossRef] 
5. Tavío, M.M.; Aquili, V.D.; Poveda, J.B.; Antunes, N.T.; Sánchez-Céspedes, J.; Vila, J. Quorum-sensing regulator sdiA and marA overexpression is involved in in vitro-selected multidrug resistance of Escherichia coli. J. Antimicrob. Chemother. 2010, 65, 1178-1186. [CrossRef]

6. Mattmann, M.E.; Shipway, P.M.; Heth, N.J.; Blackwell, H.E. Potent and selective synthetic modulators of a quorum sensing repressor in Pseudomonas aeruginosa identified from second-generation libraries of $\mathrm{N}$-acylated L-homoserine lactones. Chembiochem 2011, 12, 942-949. [CrossRef]

7. Lahiri, D.; Nag, M.; Sheikh, H.I.; Sarkar, T.; Edinur, H.; Siddhartha, P.; Ray, R. Microbiologically synthesized nanoparticles and their role in silencing the biofilm signaling cascade. Front. Microbiol. 2021. [CrossRef]

8. Amara, N.; Mashiach, R.; Amar, D.; Krief, P.; Spieser, S.A.H.; Bottomley, M.J.; Aharoni, A.; Meijler, M.M. Covalent inhibition of bacterial quorum sensing. J. Am. Chem. Soc. 2009, 131, 10610-10619. [CrossRef]

9. Lahiri, D.; Nag, M.; Sarkar, T.; Dutta, B.; Ray, R.R. Antibiofilm activity of $\alpha$-amylase from Bacillus subtilis and prediction of the optimized conditions for biofilm removal by response surface methodology (RSM) and artificial neural network (ANN). Appl. Biochem. Biotechnol. 2021. [CrossRef] [PubMed]

10. Lahiri, D.; Nag, M.; Dutta, B.; Sarkar, T.; Ray, R.R. artificial neural network and response surface methodology-mediated optimization of bacteriocin production by Rhizobium leguminosarum. Iran. J. Sci. Technol. Trans. A Sci. 2021, 45. [CrossRef]

11. Ramasamy, M.; Lee, J. Recent nanotechnology approaches for prevention and treatment of biofilm-associated infections on medical devices. Biomed Res. Int. 2016, 2016, 1851242. [CrossRef] [PubMed]

12. Qi, Y.; Nathani, A.; Zhang, J.; Song, Z.; Sharma, C.S.; Varshney, S.K. Synthesis of amphiphilic poly(ethylene glycol)-blockpoly(methyl methacrylate) containing trityl ether acid cleavable junction group and its self-assembly into ordered nanoporous thin films. e-Polymers 2020, 20, 111-121. [CrossRef]

13. Peng, P.; Yang, J.; Wu, Q.; Wu, M.; Liu, J.; Zhang, J. Fabrication of N-halamine polyurethane films with excellent antibacterial properties. e-Polymers 2021, 21, 47-56. [CrossRef]

14. Simona, J.; Dani, D.; Petr, S.; Marcela, N.; Jakub, T.; Bohuslava, T. Edible films from carrageenan/orange essential oil/trehalosestructure, optical properties, and antimicrobial activity. Polymers 2021, 13, 332. [CrossRef] [PubMed]

15. Lequette, Y.; Lee, J.-H.; Ledgham, F.; Lazdunski, A.; Greenberg, E.P. A distinct QscR regulon in the Pseudomonas aeruginosa quorum-sensing circuit. J. Bacteriol. 2006, 188, 3365-3370. [CrossRef] [PubMed]

16. Niu, C.; Clemmer, K.M.; Bonomo, R.A.; Rather, P.N. Isolation and characterization of an autoinducer synthase from Acinetobacter baumannii. J. Bacteriol. 2008, 190, 3386-3392. [CrossRef]

17. Darwish, M.; Mohammadi, A. Functionalized nanomaterial for environmental techniques. Nanotechnol. Environ. Sci. 2018, 315-350. [CrossRef]

18. Chandra Kanth, P.; Verma, S.K.; Gour, N. Chapter 10-Functionalized nanomaterials for biomedical and agriculture industries. In Micro and Nano Technologies; Mustansar Hussain, C.B.T.-H., Ed.; Elsevier: Amsterdam, The Netherlands, 2020; pp. 231-265. ISBN 978-0-12-816787-8.

19. Habimana, O.; Zanoni, M.; Vitale, S.; O'Neill, T.; Scholz, D.; Xu, B.; Casey, E. One particle, two targets: A combined action of functionalised gold nanoparticles, against Pseudomonas fluorescens biofilms. J. Colloid Interface Sci. 2018, 526, 419-428. [CrossRef]

20. Duncan, B.; Li, X.; Landis, R.F.; Kim, S.T.; Gupta, A.; Wang, L.-S.; Ramanathan, R.; Tang, R.; Boerth, J.A.; Rotello, V.M. Nanoparticle-stabilized capsules for the treatment of bacterial biofilms. ACS Nano 2015, 9, 7775-7782. [CrossRef]

21. Leuba, K.D.; Durmus, N.G.; Taylor, E.N.; Webster, T.J. Short communication: Carboxylate functionalized superparamagnetic iron oxide nanoparticles (SPION) for the reduction of S. aureus growth post biofilm formation. Int. J. Nanomed. 2013, 8, 731-736. [CrossRef]

22. Teirlinck, E.; Barras, A.; Liu, J.; Fraire, J.C.; Lajunen, T.; Xiong, R.; Forier, K.; Li, C.; Urtti, A.; Boukherroub, R.; et al. Exploring lightsensitive nanocarriers for simultaneous triggered antibiotic release and disruption of biofilms upon generation of laser-induced vapor nanobubbles. Pharmaceutics 2019, 11, 201. [CrossRef] [PubMed]

23. Lellouche, J.; Friedman, A.; Lahmi, R.; Gedanken, A.; Banin, E. Antibiofilm surface functionalization of catheters by magnesium fluoride nanoparticles. Int. J. Nanomed. 2012, 7, 1175-1188. [CrossRef]

24. Singh, A.K.; Bai, X.; Amalaradjou, M.A.R.; Bhunia, A.K. Antilisterial and antibiofilm activities of pediocin and LAP functionalized gold nanoparticles. Front. Sustain. Food Syst. 2018, 2, 74. [CrossRef]

25. Colino, C.I.; Lanao, J.M.; Gutierrez-Millan, C. Recent advances in functionalized nanomaterials for the diagnosis and treatment of bacterial infections. Mater. Sci. Eng. C 2021, 121, 111843. [CrossRef]

26. Shrestha, A.; Hamblin, M.R.; Kishen, A. Photoactivated rose bengal functionalized chitosan nanoparticles produce antibacterial/biofilm activity and stabilize dentin-collagen. Nanomedicine 2014, 10, 491-501. [CrossRef]

27. Zhu, H.; Liu, H.-J.; Ning, S.-J.; Gao, Y.-L. The response of type 2 quorum sensing in Klebsiella pneumoniae to a fluctuating culture environment. DNA Cell Biol. 2012, 31, 455-459. [CrossRef]

28. Bajdik, J.; Marciello, M.; Caramella, C.; Domján, A.; Süvegh, K.; Marek, T.; Pintye-Hódi, K. Evaluation of surface and microstructure of differently plasticized chitosan films. J. Pharm. Biomed. Anal. 2009, 49, 655-659. [CrossRef]

29. Rossi, S.; Marciello, M.; Sandri, G.; Ferrari, F.; Bonferoni, M.C.; Papetti, A.; Caramella, C.; Dacarro, C.; Grisoli, P. Wound dressings based on chitosans and hyaluronic acid for the release of chlorhexidine diacetate in skin ulcer therapy. Pharm. Dev. Technol. 2007, 12, 415-422. [CrossRef] 
30. Rossi, S.; Marciello, M.; Bonferoni, M.C.; Ferrari, F.; Sandri, G.; Dacarro, C.; Grisoli, P.; Caramella, C. Thermally sensitive gels based on chitosan derivatives for the treatment of oral mucositis. Eur. J. Pharm. Biopharm. 2010, 74, 248-254. [CrossRef]

31. Annous, B.A.; Fratamico, P.M.; Smith, J.L. Scientific status summary. J. Food Sci. 2009, 74, R24-R37. [CrossRef]

32. Atkinson, S.; Chang, C.-Y.; Sockett, R.E.; Cámara, M.; Williams, P. Quorum sensing in Yersinia enterocolitica controls swimming and swarming motility. J. Bacteriol. 2006, 188, 1451-1461. [CrossRef] [PubMed]

33. Nag, M.; Lahiri, D.; Ghosh, A.; Das, D.; Ray, R.R. Quorum sensing. In Biofilm-Mediated Diseases: Causes and Controls; Ray, R.R., Nag, M., Lahiri, D., Eds.; Springer: Singapore, 2021.

34. Wand, M.E.; Bock, L.J.; Turton, J.F.; Nugent, P.G.; Sutton, J.M. Acinetobacter baumannii virulence is enhanced in Galleria mellonella following biofilm adaptation. J. Med. Microbiol. 2012, 61, 470-477. [CrossRef] [PubMed]

35. Zhu, H.; Liu, H.-J.; Ning, S.-J.; Gao, Y.-L. A luxS-dependent transcript profile of cell-to-cell communication in Klebsiella pneumoniae Mol. Biosyst. 2011, 7, 3164-3168. [CrossRef] [PubMed]

36. Ledgham, F.; Ventre, I.; Soscia, C.; Foglino, M.; Sturgis, J.N.; Lazdunski, A. Interactions of the quorum sensing regulator QscR: Interaction with itself and the other regulators of Pseudomonas aeruginosa LasR and RhlR. Mol. Microbiol. 2003, 48, 199-210. [CrossRef] [PubMed]

37. Gram, L.; Christensen, A.B.; Ravn, L.; Molin, S.; Givskov, M. Production of acylated homoserine lactones by psychrotrophic members of the Enterobacteriaceae isolated from foods. Appl. Environ. Microbiol. 1999, 65, 3458-3463. [CrossRef]

38. Russo, T.A.; Shon, A.S.; Beanan, J.M.; Olson, R.; MacDonald, U.; Pomakov, A.O.; Visitacion, M.P. Hypervirulent, K. pneumoniae secretes more and more active iron-acquisition molecules than "classical" K. pneumoniae thereby enhancing its virulence. PLoS ONE 2011, 6, e26734. [CrossRef]

39. Sanders Jr, W.E.; Sanders, C.C. Enterobacter spp.: Pathogens poised to flourish at the turn of the century. Clin. Microbiol. Rev. 1997, 10, 220-241. [CrossRef] [PubMed]

40. Rahmati, S.; Yang, S.; Davidson, A.L.; Zechiedrich, E.L. Control of the AcrAB multidrug efflux pump by quorum-sensing regulator SdiA. Mol. Microbiol. 2002, 43, 677-685. [CrossRef]

41. González Barrios, A.F.; Zuo, R.; Hashimoto, Y.; Yang, L.; Bentley, W.E.; Wood, T.K. Autoinducer 2 controls biofilm formation in Escherichia coli through a novel motility quorum-sensing regulator (MqsR, B3022). J. Bacteriol. 2006, 188, 305-316. [CrossRef]

42. Xavier, K.B.; Miller, S.T.; Lu, W.; Kim, J.H.; Rabinowitz, J.; Pelczer, I.; Semmelhack, M.F.; Bassler, B.L. Phosphorylation and processing of the quorum-sensing molecule autoinducer-2 in enteric bacteria. ACS Chem. Biol. 2007, 2, 128-136. [CrossRef]

43. Lee, J.; Maeda, T.; Hong, S.H.; Wood, T.K. Reconfiguring the quorum-sensing regulator SdiA of Escherichia coli to control biofilm formation via indole and N-acylhomoserine lactones. Appl. Environ. Microbiol. 2009, 75, 1703-1716. [CrossRef]

44. Lim, E.-K.; Jang, E.; Lee, K.; Haam, S.; Huh, Y.-M. Delivery of cancer therapeutics using nanotechnology. Pharmaceutics 2013, 5, 294-317. [CrossRef]

45. Xue, T.; Zhao, L.; Sun, H.; Zhou, X.; Sun, B. LsrR-binding site recognition and regulatory characteristics in Escherichia coli AI-2 quorum sensing. Cell Res. 2009, 19, 1258-1268. [CrossRef] [PubMed]

46. Roy, V.; Fernandes, R.; Tsao, C.-Y.; Bentley, W.E. Cross species quorum quenching using a native AI-2 processing enzyme. ACS Chem. Biol. 2010, 5, 223-232. [CrossRef]

47. Bhargava, N.; Sharma, P.; Capalash, N. N-acyl homoserine lactone mediated interspecies interactions between A. baumannii and $P$. aeruginosa. Biofouling 2012, 28, 813-822. [CrossRef] [PubMed]

48. Khan, M.A.; Chen, L.; Liang, L. Improvement in storage stability and resveratrol retention by fabrication of hollow zein-chitosan composite particles. Food Hydrocoll. 2021, 113, 106477. [CrossRef]

49. Chatzitaki, A.-T.; Jesus, S.; Karavasili, C.; Andreadis, D.; Fatouros, D.G.; Borges, O. Chitosan-coated PLGA nanoparticles for the nasal delivery of ropinirole hydrochloride: In vitro and ex vivo evaluation of efficacy and safety. Int. J. Pharm. 2020, $589,119776$. [CrossRef] [PubMed]

50. Chandra, J.; Kuhn, D.M.; Mukherjee, P.K.; Hoyer, L.L.; McCormick, T.; Ghannoum, M.A. Biofilm formation by the fungal pathogen Candida albicans: Development, architecture, and drug resistance. J. Bacteriol. 2001, 183, 5385-5394. [CrossRef]

51. Ravishankar, R.V.; Jamuna, B.A. Nanoparticles and their potential application as antimicrobials, science against microbial pathogens: Communicating current research and technological advances. In Formatex, Microbiology Series; Méndez-Vilas, A., Ed.; SCIRP: Wuhan, China, 2011; pp. 197-209.

52. Garg, U.; Chauhan, S.; Nagaich, U.; Jain, N. Current advances in chitosan nanoparticles based drug delivery and targeting. Adv. Pharm. Bull. 2019, 9, 195-204. [CrossRef] [PubMed]

53. Ali, A.; Ahmed, S. A review on chitosan and its nanocomposites in drug delivery. Int. J. Biol. Macromol. 2018, 109, 273-286. [CrossRef] [PubMed]

54. Pati, S.; Chatterji, A.; Dash, B.P.; Nelson, B.R.; Sarkar, T.; Shahimi, S.; Edinur, H.A.; Abd Manan, T.S.B.; Jena, P.; Mohanta, Y.K.; et al. Structural characterization and antioxidant potential of chitosan by $\gamma$-irradiation from the carapace of horseshoe crab. Polymers 2020, 12, 2361. [CrossRef]

55. Pati, S.; Sarkar, T.; Sheikh, H.I.; Bharadwaj, K.K.; Mohapatra, P.K.; Chatterji, A.; Dash, B.P.; Edinur, H.A.; Nelson, B.R. $\gamma$-Irradiated chitosan from Carcinoscorpiusrotundicauda (Latreille, 1802) improves the shelf life of refrigerated aquatic products. Front. Mar. Sci. 2021, 8, 498. [CrossRef]

56. Ghormade, V.; Deshpande, M.V.; Paknikar, K.M. Perspectives for nano-biotechnology enabled protection and nutrition of plants. Biotechnol. Adv. 2011, 29, 792-803. [CrossRef] 
57. Dedloff, M.R.; Effler, C.S.; Holban, A.M.; Gestal, M.C. Use of biopolymers in mucosally-administered vaccinations for respiratory disease. Materials 2019, 12, 2445. [CrossRef] [PubMed]

58. Karava, A.; Lazaridou, M.; Nanaki, S.; Michailidou, G.; Christodoulou, E.; Kostoglou, M.; Iatrou, H.; Bikiaris, D.N. Chitosan derivatives with mucoadhesive and antimicrobial properties for simultaneous nanoencapsulation and extended ocular release formulations of dexamethasone and chloramphenicol drugs. Pharmaceutics 2020, 12, 594. [CrossRef]

59. Safdar, R.; Omar, A.A.; Arunagiri, A.; Regupathi, I.; Thanabalan, M. Potential of chitosan and its derivatives for controlled drug release applications-A review. J. Drug Deliv. Sci. Technol. 2019, 49, 642-659. [CrossRef]

60. Bowman, K.; Leong, K.W. Chitosan nanoparticles for oral drug and gene delivery. Int. J. Nanomed. 2006, 1, 117-128. [CrossRef] [PubMed]

61. Mushtaq, S.; Khan, J.A.; Rabbani, F.; Latif, U.; Arfan, M.; Yameen, M.A. Biocompatible biodegradable polymeric antibacterial nanoparticles for enhancing the effects of a third-generation cephalosporin against resistant bacteria. J. Med. Microbiol. 2017, 66, 318-327. [CrossRef] [PubMed]

62. Jhaveri, J.; Raichura, Z.; Khan, T.; Momin, M.; Omri, A. Chitosan nanoparticles-insight into properties, functionalization and applications in drug delivery and theranostics. Molecules 2021, 26, 272. [CrossRef]

63. Grenha, A. Chitosan nanoparticles: A survey of preparation methods. J. Drug Target. 2012, 20, 291-300. [CrossRef]

64. Shiraishi, S.; Imai, T.; Otagiri, M. Controlled release of indomethacin by chitosan-polyelectrolyte complex: Optimization and in vivo/in vitro evaluation. J. Control. Release 1993, 25, 217-225. [CrossRef]

65. Gondil, V.S.; Dube, T.; Panda, J.J.; Yennamalli, R.M.; Harjai, K.; Chhibber, S. Comprehensive evaluation of chitosan nanoparticle based phage lysin delivery system; a novel approach to counter S. pneumoniae infections. Int. J. Pharm. 2020, 573, 118850. [CrossRef]

66. Krishnasailaja, A.; Amareshwar, P.; Chakravarty, P. Different techniques used for the preparation of nanoparticles using natural polymers and their application. Int. J. Pharm. Pharm. Sci. 2011, 3, 45-50.

67. Rizeq, B.R.; Younes, N.N.; Rasool, K.; Nasrallah, G.K. Synthesis, bioapplications, and toxicity evaluation of chitosan-based nanoparticles. Int. J. Mol. Sci. 2019, 20, 5776. [CrossRef]

68. Calvo, P.; Remuñán-López, C.; Vila-Jato, J.L.; Alonso, M.J. Novel hydrophilic chitosan-polyethylene oxide nanoparticles as protein carriers. J. Appl. Polym. Sci. 1997, 63, 125-132. [CrossRef]

69. Divya, K.; Jisha, M.S. Chitosan nanoparticles preparation and applications. Environ. Chem. Lett. 2018, 16, 101-112. [CrossRef]

70. Jonassen, H.; Kjøniksen, A.-L.; Hiorth, M. Stability of chitosan nanoparticles cross-linked with tripolyphosphate. Biomacromolecules 2012, 13, 3747-3756. [CrossRef] [PubMed]

71. Illum, L. Chitosan and its use as a pharmaceutical excipient. Pharm. Res. 1998, 15, 1326-1331. [CrossRef] [PubMed]

72. Furtado, G.T.; Fideles, T.B.; de Cássia Alves Leal Cruz, R.; Souza, J.W.; Barbero, M.; Fook, M. Chitosan/NaF particles prepared via ionotropic gelation: Evaluation of particles size and morphology. Mater. Res. J. Mater. 2018, 21. [CrossRef]

73. Debnath, S.; Kumar, R.; Babu, M. Ionotropic gelation-A novel method to prepare chitosan nanoparticles. Res. J. Pharm. Technol. 2011, 4, 492-495.

74. De, T.; Ghosh, P.; Maitra, A.; Sahoo, S. Process for the Preparation of Highly Monodispersed Polymeric Hydrophilic Nanoparticles. U.S. Patent 5,874,111, 23 February 1999.

75. Fang, H.; Huang, J.; Ding, L.; Li, M.; Chen, Z. Preparation of magnetic chitosan nanoparticles and immobilization of laccase. J. Wuhan Univ. Technol. Sci. Ed. 2009, 24, 42-47. [CrossRef]

76. Saikia, C.; Gogoi, P. Chitosan: A promising biopolymer in drug delivery applications. J. Mol. Genet. Med. 2015, 4. [CrossRef]

77. El-Shabouri, M.H. Positively charged nanoparticles for improving the oral bioavailability of cyclosporin-A. Int. J. Pharm. 2002, 249, 101-108. [CrossRef]

78. Niwa, T.; Takeuchi, H.; Hino, T.; Kunou, N.; Kawashima, Y. Preparations of biodegradable nanospheres of water-soluble and insoluble drugs with D,L-lactide/glycolide copolymer by a novel spontaneous emulsification solvent diffusion method, and the drug release behavior. J. Control. Release 1993, 25, 89-98. [CrossRef]

79. Nagpal, K.; Singh, S.K.; Mishra, D.N. Chitosan nanoparticles: A promising system in novel drug delivery. Chem. Pharm. Bull. (Tokyo) 2010, 58, 1423-1430. [CrossRef] [PubMed]

80. Chandra Hembram, K.; Prabha, S.; Chandra, R.; Ahmed, B.; Nimesh, S. Advances in preparation and characterization of chitosan nanoparticles for therapeutics. Artif. Cells Nanomed. Biotechnol. 2016, 44, 305-314. [CrossRef] [PubMed]

81. Ibekwe, C.; Oyatogun, G.M.; Esan, T.; Oluwasegun, K. Synthesis and characterization of chitosan/gum arabic nanoparticles for bone regeneration. J. Mater. Sci. Eng. 2017, 5, $28-36$.

82. Sarmento, B.; Ribeiro, A.J.; Veiga, F.; Ferreira, D.C.; Neufeld, R.J. Insulin-loaded nanoparticles are prepared by alginate ionotropic pre-gelation followed by chitosan polyelectrolyte complexation. J. Nanosci. Nanotechnol. 2007, 7, 2833-2841. [CrossRef]

83. Zhao, L.; Shi, L.-E.; Zhang, Z.-L.; Chen, J.-M.; Shi, D.; Yang, J.; Tang, Z.-X. Preparation and application of chitosan nanoparticles and nanofibers. Braz. J. Chem. Eng. 2011, 28, 353-362. [CrossRef]

84. Brunel, F.; Véron, L.; David, L.; Domard, A.; Delair, T. A novel synthesis of chitosan nanoparticles in reverse emulsion. Langmuir 2008, 24, 11370-11377. [CrossRef]

85. Del Prado-Audelo, M.L.; Caballero-Florán, I.H.; Sharifi-Rad, J.; Mendoza-Muñoz, N.; González-Torres, M.; Urbán-Morlán, Z.; Florán, B.; Cortes, H.; Leyva-Gómez, G. Chitosan-decorated nanoparticles for drug delivery. J. Drug Deliv. Sci. Technol. 2020, 59, 101896. [CrossRef] 
86. Liang, Y.; Wang, Y.; Wang, L.; Liang, Z.; Li, D.; Xu, X.; Chen, Y.; Yang, X.; Zhang, H.; Niu, H. Self-crosslinkable chitosan-hyaluronic acid dialdehyde nanoparticles for CD44-targeted siRNA delivery to treat bladder cancer. Bioact. Mater. 2021, 6, 433-446. [CrossRef] [PubMed]

87. Masjedi, M.; Azadi, A.; Heidari, R.; Mohammadi-Samani, S. Brain targeted delivery of sumatriptan succinate loaded chitosan nanoparticles: Preparation, in vitro characterization, and (neuro-)pharmacokinetic evaluations. J. Drug Deliv. Sci. Technol. 2021, 61, 102179. [CrossRef]

88. Babii, O.; Wang, Z.; Liu, G.; Martinez, E.C.; van DrunenLittel-van den Hurk, S.; Chen, L. Low molecular weight chitosan nanoparticles for $\mathrm{CpG}$ oligodeoxynucleotides delivery: Impact of molecular weight, degree of deacetylation, and mannosylation on intracellular uptake and cytokine induction. Int. J. Biol. Macromol. 2020, 159, 46-56. [CrossRef] [PubMed]

89. de Andrade, L.F.; Apolinário, A.C.; Rangel-Yagui, C.O.; Stephano, M.A.; Tavares, L.C. Chitosan nanoparticles for the delivery of a new compound active against multidrug-resistant Staphylococcus aureus. J. Drug Deliv. Sci. Technol. 2020, 55, 101363. [CrossRef]

90. Akhtar, B.; Muhammad, F.; Aslam, B.; Saleemi, M.K.; Sharif, A. Pharmacokinetic profile of chitosan modified poly lactic co-glycolic acid biodegradable nanoparticles following oral delivery of gentamicin in rabbits. Int. J. Biol. Macromol. 2020, 164, 1493-1500. [CrossRef] [PubMed]

91. Nasri, R.; Hamdi, M.; Touir, S.; Li, S.; Karra-Chaâbouni, M.; Nasri, M. Development of delivery system based on marine chitosan: Encapsulationand release kinetic study of antioxidant peptides from chitosan microparticle. Int. J. Biol. Macromol. 2021, 167, 1445-1451. [CrossRef] [PubMed]

92. Afshar, M.; Dini, G.; Vaezifar, S.; Mehdikhani, M.; Movahedi, B. Preparation and characterization of sodium alginate/polyvinyl alcohol hydrogel containing drug-loaded chitosan nanoparticles as a drug delivery system. J. Drug Deliv. Sci. Technol. 2020, 56, 101530. [CrossRef]

93. Wang, Y.; Zhou, C.; Ding, Y.; Liu, M.; Tai, Z.; Jin, Q.; Yang, Y.; Li, Z.; Yang, M.; Gong, W.; et al. Red blood cell-hitchhiking chitosan nanoparticles for prolonged blood circulation time of vitamin K1. Int. J. Pharm. 2021, 592, 120084. [CrossRef] [PubMed]

94. Wang, J.; Chin, D.; Poon, C.; Mancino, V.; Pham, J.; Li, H.; Ho, P.-Y.; Hallows, K.R.; Chung, E.J. Oral delivery of metformin by chitosan nanoparticles for polycystic kidney disease. J. Control. Release 2021, 329, 1198-1209. [CrossRef] [PubMed]

95. Sohail, R.; Abbas, S.R. Evaluation of amygdalin-loaded alginate-chitosan nanoparticles as biocompatible drug delivery carriers for anticancerous efficacy. Int. J. Biol. Macromol. 2020, 153, 36-45. [CrossRef]

96. Sava, V.; Fihurka, O.; Khvorova, A.; Sanchez-Ramos, J. Data on enrichment of chitosan nanoparticles for intranasal delivery of oligonucleotides to the brain. Data Br. 2020, 28, 105093. [CrossRef]

97. Wang, F.; Li, J.; Tang, X.; Huang, K.; Chen, L. Polyelectrolyte three layer nanoparticles of chitosan/dextran sulfate/chitosan for dual drug delivery. Colloids Surf. B Biointerfaces 2020, 190, 110925. [CrossRef]

98. Khalil, R.M.; El Arini, S.K.; AbouSamra, M.M.; Zaki, H.S.; El-Gazaerly, O.N.; Elbary, A.A. Development of lecithin/chitosan nanoparticles for promoting topical delivery of propranolol hydrochloride: Design, optimization and in-vivo evaluation. J. Pharm. Sci. 2021, 110, 1337-1348. [CrossRef] [PubMed]

99. Sudhakar, S.; Chandran, S.V.; Selvamurugan, N.; Nazeer, R.A. Biodistribution and pharmacokinetics of thiolated chitosan nanoparticles for oral delivery of insulin in vivo. Int. J. Biol. Macromol. 2020, 150, 281-288. [CrossRef] [PubMed]

100. George, D.; Maheswari, P.U.; Begum, K.M.M.S. Chitosan-cellulose hydrogel conjugated with L-histidine and zinc oxide nanoparticles for sustained drug delivery: Kinetics and in-vitro biological studies. Carbohydr. Polym. 2020, 236, 116101. [CrossRef] [PubMed]

101. Shakeran, Z.; Keyhanfar, M.; Varshosaz, J.; Sutherland, D.S. Biodegradable nanocarriers based on chitosan-modified mesoporous silica nanoparticles for delivery of methotrexate for application in breast cancer treatment. Mater. Sci. Eng. C 2021, 118, 111526. [CrossRef] [PubMed]

102. Li, J.; Jin, X.; Zhang, L.; Yang, Y.; Liu, R.; Li, Z. Comparison of different chitosan lipid nanoparticles for improved ophthalmic tetrandrine delivery: Formulation, characterization, pharmacokinetic and molecular dynamics simulation. J. Pharm. Sci. 2020, 109, 3625-3635. [CrossRef]

103. Subbiah, L.; Palanisamy, S.; Thamizhmurasu, S.; Mathew Joseph, A.B.; Thangavelu, P.; Ganeshan, M.; ThimiriGovinda Raj, D.B. Development of Meloxicam-chitosan magnetic nanoconjugates for targeting rheumatoid arthritis joints: Pharmaceutical characterization and preclinical assessment on murine models. J. Magn. Magn. Mater. 2021, 523, 167571. [CrossRef]

104. Bellich, B.; D'Agostino, I.; Semeraro, S.; Gamini, A.; Cesàro, A. “The Good, the Bad and the Ugly" of Chitosans. Mar. Drugs 2016, 14, 99. [CrossRef]

105. Roy, S.G.; Shirsat, N.S.; Mishra, A.C.; Waghulde, S.O.; Kale, M.K. A review on chitosan nanoparticles applications in drug delivery. J. Pharmacogn. Phytochem. 2018, 7, 01-04. [CrossRef]

106. Bernkop-Schnürch, A.; Dünnhaupt, S. Chitosan-based drug delivery systems. Eur. J. Pharm. Biopharm. 2012, 81, 463-469. [CrossRef]

107. Gadkari, R.R.; Suwalka, S.; Yogi, M.R.; Ali, W.; Das, A.; Alagirusamy, R. Green synthesis of chitosan-cinnamaldehyde cross-linked nanoparticles: Characterization and antibacterial activity. Carbohydr. Polym. 2019, 226, 115298. [CrossRef]

108. Mescola, A.; Canale, C.; Fragouli, D.; Athanassiou, A. Controlled formation of gold nanostructures on biopolymer films upon electromagnetic radiation. Nanotechnology 2017, 28, 415601. [CrossRef]

109. Nagaonkar, D.; Gaikwad, S.; Rai, M. Catharanthus roseus leaf extract-synthesized chitosan nanoparticles for controlled in vitro release of chloramphenicol and ketoconazole. Colloid Polym. Sci. 2015, 293, 1465-1473. [CrossRef] 
110. Galié, S.; García-Gutiérrez, C.; Miguélez, E.M.; Villar, C.J.; Lombó, F. Biofilms in the Food Industry: Health Aspects and Control Methods. Front. Microbiol. 2018, 9, 898. [CrossRef]

111. Wang, L.; Hashimoto, Y.; Tsao, C.-Y.; Valdes, J.J.; Bentley, W.E. Cyclic AMP (cAMP) and cAMP receptor protein influence both synthesis and uptake of extracellular autoinducer 2 in Escherichia coli. J. Bacteriol. 2005, 187, 2066-2076. [CrossRef] [PubMed]

112. Zhou, X.; Meng, X.; Sun, B. An EAL domain protein and cyclic AMP contribute to the interaction between the two quorum sensing systems in Escherichia coli. Cell Res. 2008, 18, 937-948. [CrossRef] [PubMed]

113. Tan, Y.; Ma, S.; Leonhard, M.; Moser, D.; Haselmann, G.M.; Wang, J.; Eder, D.; Schneider-Stickler, B. Enhancing antibiofilm activity with functional chitosan nanoparticles targeting biofilm cells and biofilm matrix. Carbohydr. Polym. 2018, 200, 35-42. [CrossRef] [PubMed]

114. Yang, Y.-X.; Xu, Z.-H.; Zhang, Y.-Q.; Tian, J.; Weng, L.-X.; Wang, L.-H. A new quorum-sensing inhibitor attenuates virulence and decreases antibiotic resistance in Pseudomonas aeruginosa. J. Microbiol. 2012, 50, 987-993. [CrossRef]

115. Geske, G.D.; O’Neill, J.C.; Miller, D.M.; Mattmann, M.E.; Blackwell, H.E. Modulation of bacterial quorum sensing with synthetic ligands: Systematic evaluation of $\mathrm{N}$-acylated homoserine lactones in multiple species and new insights into their mechanisms of action. J. Am. Chem. Soc. 2007, 129, 13613-13625. [CrossRef]

116. De Lamo Marin, S.; Xu, Y.; Meijler, M.M.; Janda, K.D. Antibody catalyzed hydrolysis of a quorum sensing signal found in Gram-negative bacteria. Bioorg. Med. Chem. Lett. 2007, 17, 1549-1552. [CrossRef] [PubMed]

117. Xu, N.; Yu, S.; Moniot, S.; Weyand, M.; Blankenfeldt, W. Crystallization and preliminary crystal structure analysis of the ligandbinding domain of PqsR (MvfR), the Pseudomonas quinolone signal (PQS) responsive quorum-sensing transcription factor of Pseudomonas aeruginosa. Acta Crystallogr. Sect. F Struct. Biol. Cryst. Commun. 2012, 68, 1034-1039. [CrossRef]

118. Kaufmann, G.F.; Park, J.; Mee, J.M.; Ulevitch, R.J.; Janda, K.D. The quorum quenching antibody RS2-1G9 protects macrophages from the cytotoxic effects of the Pseudomonas aeruginosa quorum sensing signalling molecule N-3-oxo-dodecanoyl-homoserine lactone. Mol. Immunol. 2008, 45, 2710-2714. [CrossRef] [PubMed]

119. Pustelny, C.; Albers, A.; Büldt-Karentzopoulos, K.; Parschat, K.; Chhabra, S.R.; Cámara, M.; Williams, P.; Fetzner, S. Dioxygenasemediated quenching of quinolone-dependent quorum sensing in Pseudomonas aeruginosa. Chem. Biol. 2009, 16, $1259-1267$. [CrossRef]

120. Calfee, M.W.; Coleman, J.P.; Pesci, E. Interference with Pseudomonas quinolone signal synthesis inhibits virulence factor expression by Pseudomonas aeruginosa. Proc. Natl. Acad. Sci. USA 2001, 98, 11633-11637. [CrossRef]

121. Lesic, B.; Lépine, F.; Déziel, E.; Zhang, J.; Zhang, Q.; Padfield, K.; Castonguay, M.-H.; Milot, S.; Stachel, S.; Tzika, A.A.; et al. Inhibitors of pathogen intercellular signals as selective anti-infective compounds. PLoS Pathog. 2007, 3, 1229-1239. [CrossRef] [PubMed]

122. Plyuta, V.; Zaitseva, J.; Lobakova, E.; Zagoskina, N.; Kuznetsov, A.; Khmel, I. Effect of plant phenolic compounds on biofilm formation by Pseudomonas aeruginosa. APMIS 2013, 121, 1073-1081. [CrossRef] [PubMed]

123. Adonizio, A.; Leal, S.M.; Ausubel, F.M.; Mathee, K. Attenuation of Pseudomonas aeruginosa virulence by medicinal plants in a Caenorhabditis elegans model system. J. Med. Microbiol. 2008, 57, 809-813. [CrossRef]

124. Sarabhai, S.; Sharma, P.; Capalash, N. Ellagic acid derivatives from Terminalia chebula Retz. downregulate the expression of quorum sensing genes to attenuate Pseudomonas aeruginosa PAO1 virulence. PLoS ONE 2013, 8, e53441. [CrossRef] [PubMed]

125. Zimmer, K.R.; Macedo, A.J.; Nicastro, G.G.; Baldini, R.L.; Termignoni, C. Egg wax from the cattle tick Rhipicephalus (Boophilus) microplus inhibits Pseudomonas aeruginosa biofilm. Ticks Tick. Borne. Dis. 2013, 4, 366-376. [CrossRef]

126. Skindersoe, M.E.; Ettinger-Epstein, P.; Rasmussen, T.B.; Bjarnsholt, T.; de Nys, R.; Givskov, M. Quorum sensing antagonism from marine organisms. Mar. Biotechnol. (NY) 2008, 10, 56-63. [CrossRef]

127. Gutierrez, J.A.; Crowder, T.; Rinaldo-Matthis, A.; Ho, M.-C.; Almo, S.C.; Schramm, V.L. Transition state analogs of 5'methylthioadenosine nucleosidase disrupt quorum sensing. Nat. Chem. Biol. 2009, 5, 251-257. [CrossRef] [PubMed]

128. Vikram, A.; Jesudhasan, P.R.; Pillai, S.D.; Patil, B.S. Isolimonic acid interferes with Escherichia coli O157:H7 biofilm and TTSS in QseBC and QseA dependent fashion. BMC Microbiol. 2012, 12, 261. [CrossRef] [PubMed]

129. Vila-Sanjurjo, C.; Hembach, L.; Netzer, J.; Remuñán-López, C.; Vila-Sanjurjo, A.; Goycoolea, F.M. Covalently and ionically, dually crosslinked chitosan nanoparticles block quorum sensing and affect bacterial cell growth on a cell-density dependent manner. J. Colloid Interface Sci. 2020, 578, 171-183. [CrossRef] [PubMed]

130. Qin, X.; Kräft, T.; Goycoolea, F.M. Chitosan encapsulation modulates the effect of trans-cinnamaldehyde on AHL-regulated quorum sensing activity. Colloids Surf. B Biointerfaces 2018, 169, 453-461. [CrossRef] [PubMed]

131. Sun, Y.; Qin, H.; Yan, Z.; Zhao, C.; Ren, J.; Qu, X. Combating biofilm associated infection in vivo: Integration of quorum sensing inhibition and photodynamic treatment based on multidrug delivered hollow carbon nitride sphere. Adv. Funct. Mater. 2019, 29, 1808222. [CrossRef]

132. Lichter, J.A.; Rubner, M.F. Polyelectrolyte multilayers with intrinsic antimicrobial functionality: The importance of mobile polycations. Langmuir 2009, 25, 7686-7694. [CrossRef] [PubMed]

133. Leroueil, P.R.; Hong, S.; Mecke, A.; Baker, J.R.; Orr, B.G.; Banaszak Holl, M.M. Nanoparticle interaction with biological membranes: Does nanotechnology present a Janus face? Acc. Chem. Res. 2007, 40, 335-342. [CrossRef] [PubMed]

134. Chen, K.L.; Bothun, G.D. Nanoparticles meet cell membranes: Probing nonspecific interactions using model membranes. Environ. Sci. Technol. 2014, 48, 873-880. [CrossRef] 
135. Lin, J.; Miao, L.; Zhong, G.; Lin, C.-H.; Dargazangy, R.; Alexander-Katz, A. Understanding the synergistic effect of physicochemical properties of nanoparticles and their cellular entry pathways. Commun. Biol. 2020, 3, 205. [CrossRef] [PubMed]

136. Slavin, Y.N.; Asnis, J.; Häfeli, U.O.; Bach, H. Metal nanoparticles: Understanding the mechanisms behind antibacterial activity. J. Nanobiotechnol. 2017, 15, 65. [CrossRef] [PubMed]

137. Nevius, B.A.; Chen, Y.P.; Ferry, J.L.; Decho, A.W. Surface-functionalization effects on uptake of fluorescent polystyrene nanoparticles by model biofilms. Ecotoxicology 2012, 21, 2205-2213. [CrossRef]

138. Shi, Z.; Neoh, K.G.; Kang, E.T.; Wang, W. Antibacterial and mechanical properties of bone cement impregnated with chitosan nanoparticles. Biomaterials 2006, 27, 2440-2449. [CrossRef]

139. Giglio, E.; Trapani, A.; Cafagna, D.; Ferretti, C.; Iatta, R.; Cometa, S.; Ceci, E.; Romanelli, A.; Mattioli-Belmonte, M. Ciprofloxacinloaded chitosan nanoparticles as titanium coatings: A valuable strategy to prevent implant-associated infections. Nano Biomed. Eng. 2012, 4, 163-169. [CrossRef]

140. Huang, J.-F.; Zhong, J.; Chen, G.-P.; Lin, Z.-T.; Deng, Y.; Liu, Y.-L.; Cao, P.-Y.; Wang, B.; Wei, Y.; Wu, T.; et al. A hydrogel-based hybrid theranostic contact lens for fungal keratitis. ACS Nano 2016, 10, 6464-6473. [CrossRef] 